
VOLUME 10 NOMOR 4 AGUSTUS 2021

ISSN : 2303-1514 | E-ISSN : 2598-5949

\title{
USING TEAMS GAMES TOURNAMENT (TGT) MODEL ASSOCIATED WITH SNAKES AND LADDER GAMES MEDIA TO IMPROVE STUDENTS' LEARNING ACTIVITIES AT GRADE V OF SDN 13 KAPALO KOTO, PADANG
}

\author{
Dea Sinta Maharani ${ }^{1}$, Junaidi Indrawadi ${ }^{2}$, Ulil Amri ${ }^{3}$
}

${ }^{1,2}$ Universitas Negeri Padang, Padang, Indonesia

${ }^{3}$ SD Negeri 13 Kapalo Koto, Padang, Indonesia

1'deasintamaharani1212@gmail.com, ${ }^{2}$ junaidi.indra@fis.unp.ac.id, ${ }^{3}$ ulilamritanjung@gmail.com

\section{PENGGUNAAN MODEL TEAMS GAMES TOURNAMENT (TGT) BERBANTUAN MEDIA PERMAINAN ULAR TANGGA UNTUK MENINGKATKAN AKTIVITAS BELAJAR SISWA KELAS V SDN 13 KAPALO KOTO KOTA PADANG}

\section{ARTICLE HISTORY}

Submitted:

10 Juli 2021

$10^{\text {th }}$ July 2021

Accepted:

07 Agustus 2021

$07^{\text {th }}$ August 2021

Published:

27 Agustus 2021

$27^{\text {th }}$ August 2021

\section{ABSTRACT}

Abstract: This research was motivated by the results of observations that students' learning activities were still low. This was due to the Covid-19 pandemic that hit the world so that the learning process was carried out online. The online learning process did not stimulate students to carry out learning activities so that the students' learning activities were low. This study aimed to increase students' learning activities by using Cooperative learning model of the Teams Games Tournament (TGT) type assisted by the snake and ladder game media. This research was classroom action research consisting of two cycles with 4 stages, namely planning, implementation, observation and reflection. The subjects of this study were 31 students of class VB. The data collection method used in this research was observation. The results showed that the average percentage of students' learning activities classically increased. This was seen from the results of observations of students' learning activities in cycle 1 which was $64.52 \%$ and in cycle 2 for $85.28 \%$. Based on the results of this study, it was concluded that using TGT type cooperative model with snakes and ladders game media improved students' learning activities.

Keywords: TGT, snake ladder games, learning activities.

Abstrak: Penelitian ini dilatar belakangi dengan hasil observasi yang dilakukan di kelas VB SDN 13 Kapalo Koto menunjukkan bahwa aktivitas belajar siswa masih rendah. Hal ini dikarenakan pandemi Covid-19 yang melanda dunia sehingga proses pembelajaran dilakukan secara daring, proses pembelajaran daring tidak dapat menstimulasi siswa untuk melakukan aktivitas belajar sehingga pada saat belajar di dalam kelas aktivitas belajar siswa rendah. Penelitian ini bertujuan untuk meningkatkan aktivitas belajar siswa menggunakan model pembelajaran Kooperatif tipe Teams Games Tournament (TGT) berbantuan media permainan ular tangga. Jenis penelitian yang digunakan adalah penelitian tindakan kelas yang terdiri dari dua siklus dengan 4 tahapan yaitu perencanaan, pelaksanaan, pengamatan dan refleksi. Subjek penelitian ini adalah siswa kelas VB dengan jumlah 31 siswa. Metode pengumpulan data yang digunakan adalah observasi. Hasil penelitian menunjukkan bahwa rata-rata persentase aktivitas belajar siswa secara klasikal mengalami peningkatan. Hal ini dilihat dari hasil pengamatan aktivitas belajar siswa pada siklus 1 adalah $64.52 \%$ dan siklus 2 adalah 85.28\%. Berdasarkan hasil penelitian tersebut dapat disimpulkan bahwa penggunaan model kooperatif tipe TGT berbantuan media permainan ular tangga dapat meningkatkan aktivitas belajar siswa.

Kata Kunci: TGT, ular tangga, aktivitas belajar.

\section{CITATION}

Maharani, D. S, Indrawadi, J., Amri, U. (2021). Using Teams Games Tournament (Tgt) Model Associated with Snakes and Ladder Games Media to Improve Students' Learning Activities at Grade V of SDN 13 Kapalo Koto, Padang. Primary: Jurnal Pendidikan Guru Sekolah Dasar, 10 (4), 1069-1078. DOI: http://dx.doi.org/10.33578/jpfkip.v10i4.8474 . 


\section{PENDAHULUAN}

Pandemi COVID-19 (Coronavirus Disease-19) telah mempengaruhi sistem pendidikan di seluruh dunia. Pandemi Covid19 telah mendorong Kementrian Pendidikan dan Kebudayaan (Kemendikbud) melakukan berbagai penyesuaian pembelajaran selama masa pandemic yang salah satunya adalah kebijakan melaksanakan pembelajaran dari rumah (daring) secara nasional sejak 16 Maret 2020. Pembelajaran daring tentu saja merupakan hal yang baru bagi sebagian besar siswa di Indonesia, menurut survey yang dilakukan UNICEF pada tahun 2020 menyatakan bahwa $66 \%$ dari 60 juta siswa dari berbagai jenjang pendidikan di Indonesia mengaku tidak nyaman melakukan pembelajaran dari rumah sehingga hal tersebut menyebabkan siswa tidak bersemangat mengikuti pembelajaran daring (Kasih, 2020).

Setelah satu tahun berlalu, penyebaran COVID-19 di Indonesia mengalami kenaikan yang signifikan, namun beberapa daerah zona hijau mulai mengambil kebijakan untuk melakukan pembelajaran tatap muka dengan sistem 2 shift (sejak Januari 2021). Permasalahan-permasalahan baru akibat pembelajaran daring mulai bermunculan yang salah satunya adalah pembelajaran daring interaksi antara siswa dan guru tidak berjalan dengan baik sehingga proses pembelajaran menjadi tidak efektif (Jusman, 2021) dan proses pembelajaran yang tidak efektif tersebut tidak dapat menstimulasi aktivitas belajar siswa.

Aktivitas belajar merupakan seluruh kegiatan yang dilakukan siswa selama proses pembelajaran berlangsung (Hamalik, 2013). Aktivitas belajar merupakan hal yang sangat penting bagi siswa, karena memberikan kesempatan kepada siswa untuk bersentuhan dengan obyek yang sedang dipelajari seluas mungkin, karena dengan demikian proses konstruksi pengetahuan yang terjadi akan lebih baik. Aktivitas Belajar diperlukan karena pada prinsipnya belajar adalah proses mengubah tingkah laku, jadi melakukan kegiatan. Sardiman (2012) menyatakan bahwa aktivitas belajar merupakan aktivitas yang bersifat mental maupun fisik. Aktivitas belajar siswa disekolah cukup kompleks dan bervariasi. Jika berbagai macam kegiatan tersebut dapat diciptakan di sekolah, maka sekolah akan benar-benar menjadi pusat aktivitas belajar yang maksimal sehingga dapat meningkatkan hasil belajar siswa. Dalam penelitian ini aktivitas yang diamati meliputi visual activities, oral activities, listening activities, writing activities, drawing activities, dan mental activities (Agustin, dkk. 2017). Hal ini sejalan dengan aspek-askpek aktivitas belajar yang dikemukakan Diedrich (Aminah, 2018), aktivitas belajar siswa memiliki 8 aspek yang terdiri dari aktivitas visual, lisan, mendengarkan, menulis, menggambar, fisik, mental dan emosional.

Rendahnya kualitas aktivitas belajar siswa yang disebabkan oleh pandemi juga peneliti temukan dalam proses pembelajaran di kelas VB SD Negeri 13 Kapalo Koto. Berdasarkan hasil observasi yang dilakukan di kelas VB SDN 13 Kapalo Koto, peneliti menemukan kualitas aktivitas belajar siswa saat pandemi masih sangat rendah yaitu sebesar 50.1\% dengan kualifikasi kurang (D).

Berdasarkan data di atas dapat dilihat bahwa aktivitas belajar siswa di kelas VB SD Negeri 13 Kapalo Koto masih sangat rendah karena hanya $50.1 \%$ siswa yang terlibat aktif dalam proses pembelajaran sedangkan menurut pendapat Mulyasa (Wibowo, 2016) dari segi proses, pembelajaran dikatakan berhasil dan berkualitas apabila seluruhnya atau setidaktidaknya sebagian besar $(75 \%)$ siswa terlibat aktif dalam proses pembelajaran.

Berdasarkan identifikasi masalah tersebut, diperlukan adanya suatu perbaikan terhadap aktivitas pembelajaran karena tanpa aktivitas proses pembelajaran tidak mungkin berlangsung dengan baik (Tarigan, 2014). Hal ini sejalan dengan pendapat Natawijaya (Meipina, 2014) yang menyatakan bahwa 
belajar aktif adalah suatu sistem belajar mengajar yang menekankan keaktifan siswa secara fisik, mental intelektual dan emosional guna memperoleh hasil belajar berupa perpaduan antara aspek kognitif, afektif dan psikomotor. Maka dari itu masalah utama yang harus segera diatasi yakni terkait dengan aktivitas belajar siswa yang rendah.

Cara yang dapat digunakan guru untuk meningkatkan aktivitas belajar siswa adalah dengan menggunakan model pembelajaran yang dapat mengasah aktivitas belajar siswa. Hal ini sejalan dikarenakan sistem pembelajaran yang memberi kesempatan kepada siswa untuk aktif melakukan kegiatan dalam proses pembelajaran dan menyebabkan siswa termotivasi untuk mempelajari suatu materi pembelajaran, sehingga apa yang diperoleh siswa dari belajar akan tersimpan lama(Anggraeni, dkk. 2018). Salah satu model yang dianggap sesuai untuk meningkatkan aktivitas belajar siswa adalah model pembelajaran kooperatif tipe Teams Games Tournament (TGT).

Model pembelajaran kooperatif tipe Teams Games Tournament (TGT) salah satu tipe atau model pembelajaran kooperatif yang mudah diterapkan, melibatkan aktivitas seluruh siswa tanpa harus ada perbedaan status, melibatkan peran siswa sebagai tutor sebaya dan mengandung unsur permainan dan penguatan (Chikmaeati, dkk. 2013). Keunggulan pembelajaran tipe TGT adalah adanya turnamen akademik dalam proses pembelajaran (Yudianto, dkk. 2014). Menurut Isjoni (Maulidina, 2018) model pembelajaran kooperatif tipe TGT merupakan model pembelajaran yang menempatkan siswa ke dalam kelompok belajar yang terdiri dari 5-6 orang yang memiliki kemampuan, jenis kelamin, dan perbedaan lain yang membuat kelompok tersebut menjadi heterogen.

Dalam model pembelajaran kooperatif tipe TGT siswa akan diajak belajar, berdiskusi, menemukan masalah, menganalisis masalah dan menyelesaikan tantangan permainan bersama kelompok (Bunga, 2013). Model pembelajaran ini dapat meningkatkan kinerja pengajaran guru dan prestasi belajar siswa, serta merupakan suatu kiat, petunjuk, strategi, dan seluruh proses belajar yang dapat mempertajam pemahaman daya ingat, serta belajar sebagai proses yang menyenangkan dan bermakna (Susanna, 2017). Model kooperatif tipe TGT merupakan model pembelajaran yang dikombinasikan bersama dengan permainan atau pertandingan yang dapat dilakukan bersamaan dengan pembelajaran, salah satu media permainan yang tepat untuk dikombinasikan bersama dengan model kooperatif tipe TGT adalah permainan ular tangga (Fitrizah, 2020).

Menurut Slavin (Maulidina, 2018) model pembelajaran kooperatif tipe TGT dapat dilaksanakan dengan melakukan 5 langkah berikut, yaitu tahap penyajian kelas (class presentation), belajar dalam kelompok (teams), permainan (games), pertandingan (tournament) dan penghargaan kelompok (team reinforcement). Langkah-langkah model kooperatif tipe TGT tersebut dikolaborasikan dengan media permainan ular tangga yang pada proses pembelajaran sedang berlangsung maka siswa akan melakukan tournament permaianan ular tangga di dalam kelompok belajar yang akan telah dibentuk.

Dengan melaksanakan pembelajaran menggunakan model pembelajaran kooperatif tipe TGT berbantuan media permainan ular tangga diharapkan dapat menstimulasi siswa untuk melakukan aktivitas-aktivitas belajar sesuai dengan aspek-aspek aktivitas belajar yang telah dikemukakan sebelumnya. Hal ini sejalan dengan pendapat Sholihah (2016) yang menyatakan bahwa pemilihan model pembelajaran ini merupakan model pembelajaran alternatif yang menarik dan melibatkan siswa secara aktif, yang pada akhirnya diharapkan dapat meningkatkan aktivitas belajar siswa.

\section{METODE PENELITIAN}

Penelitian ini dilakukan di kelas VB SDN 13 Kapalo Koto Kota Padang dengan 
subjek penelitian yang berjumlah 31 orang siswa yang terdiri dari 11 orang siswa perempuan dan 20 orang siswa laki-laki. Penelitian ini bertujuan untuk mengetahui peningkatan aktivitas belajar siswa setelah menggunakan model pembelajaran kooperatif tipe TGT berbantuan media permainan ular tangga.

Penelitian ini merupakan penelitian tindakan kelas (PTK) atau yang sering disebut dengan classroom action research yang dilaksanakan selama dua siklus, dimana siklus 1 dilaksanakan dengan 2 pertemuan dan siklus 2 dilaksanakan dengan 1 pertemuan. Alur penelitian yang dipakai pada penelitian ini berpedoman pada model penelitian tindakan kelas yang dikemukakan Kemmis dan McTanggart yang pada hakikatnya berupa perangkat-perangkat atau untaian-untaian dengan satu perangkat terdiri dari empat komponen yaitu perencanaan, tindakan, pengamatan dan refleksi. Keempat komponen yang berupa untaian tersebut dipandang sebagai satu siklus (Arikunto, 2015).

Teknik pengumpulan data pada penelitian ini menggunakan lembar observasi. Selain itu data yang telah dikumpulkan pada penelitian ini dianalisis dengan menggunakan teknik analisis data kuantitatif dan kualitatif. Analisis data kualitatif dilakukan terhadap data yang berupa informasi dan uraian yang berupa penjelasan-penjelasan sedangkan analisis data kuantitatif digunakan untuk menghitung persentase hasil pengamatan perencanaan pembelajaran, pelaksanaan proses pembelajaran aspek guru dan siswa dengan menggunakan model Kooperatif Tipe TGT dan hasil pengamatan aktivitas siswa yang diperoleh.

\section{HASIL DAN PEMBAHASAN}

Penelitian ini dimulai pada tanggal 15 Maret 2021 sampai dengan tanggal 5 April 2021. Pelaksanaan penelitian tindakan kelas ini dibagi menjadi dua siklus dimana siklus I terdiri dari dua kali pertemuan dan siklus II satu kali pertemuan dengan rentang waktu dua minggu pada setiap siklusnya. Selama melakukan penelitian ini, peneliti berkolaborasi dengan guru kelas dan teman sejawat yang membantu melaksanakan penelitian ini.

Hasil peneltian ini meliputi: RPP dengan penerapan model kooperatif tipe TGT berbantuan media permainan ular tangga untuk meningkatkan aktivitas belajar siswa di kelas VB SDN 13 Kapalo Koto Kota Padang, pelaksanaan pembelajaran dengan penerapan model kooperatif tipe TGT berbantuan media permainan ular tangga untuk meningkatkan aktivitas belajar siswa di kelas VB SDN 13 Kapalo Koto Kota Padang, dan peningkatkan aktivitas belajar siswa menggunakan model kooperatif tipe TGT berbantuan media permainan ular tangga untuk meningkatkan aktivitas belajar siswa di kelas VB SDN 13 Kapalo Koto Kota Padang.

\section{Rencana Pelaksanaan Pembelajaran Siklus}

Perencanaan mutlak diperlukan agar pembelajaran tidak menyimpang dari tujuan yang ingin dicapai. Perencanaan yang dimaksud dalam penelitian ini adalah Rencana Pelaksanaan Pembelajaran (RPP).

Menurut Kunandar (2011) RPP adalah rencana yang menggambarkan prosedur dan pengorganisasian pembelajaran untuk mencapai satu kompetensi dasar yang ditetapkan dalam Standar Isi dan dijabarkan dalam silabus. Dengan demikian RPP merupakan upaya untuk memperkirakan tindakan yang akan dilakukan dalam kegiatan pembelajaran, sebagai acuan bagi guru untuk melaksanakan kegiatan pembelajaran agar lebih terarah dan berjalan secara efektif dan efesien.

Rencna pelaksanaan pembelajaran ini disusun secara kaloboratif antara peneliti dengan guru kelas (observer) sebelum dilaksanakannya penelitian. Rencana Pelaksanaan Pembelajaran ini dinilai oleh observer (guru kelas) berdasarkan instrumen penilaian yang diberikan. Instrumen penilaian tersebut berdasarkan pada pendapat Kunandar 
(2011) menyatakan bahwa instrumen penilaian RPP yaitu: a) kejelasan perumusan tujuan pembelajaran, b) pemilihan materi ajar, c) pengorganisasian materi ajar, d) pemilihan sumber/media pembelajaran, e) kejelasan proses pembelajaran, f) teknik pembelajaran, dan g) kelengkapan instrument.

Berdasarkan analisis data pada lembaran pengamatan RPP yang di isi oleh observer (guru kelas) pada penelitian ini menunjukkan bahwa perolehan skor RPP terus meningkat dan peneliti terus melakukan perbaikan pada setiap pertemuan yang dilakukan selama penelitian. Hal ini terlihat melalui kualifikasi pengamatan RPP yang terus meningkat, perolehan skor pengamatan RPP dapat dilihat secara rinci pada gambar berikut ini:

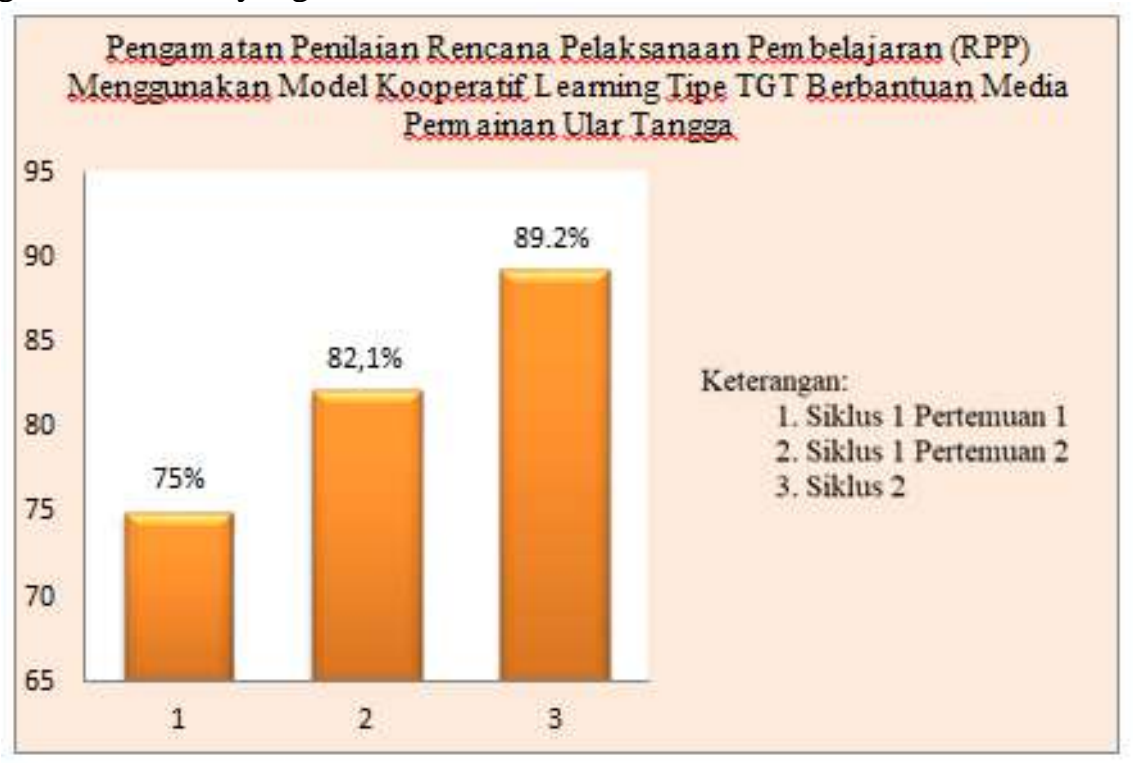

\section{Gambar 1 Pengamatan RPP}

Melalui gambar di atas dapat diketahui bahwa hasil pengamatan RPP pada penelitian ini terus meningkat, hal ini terlihat melalui perolehan skor pada siklus 1 pertemuan 1 sebesar $75 \%$ dengan kualifikasi cukup (C), siklus 1 pertemuan 2 sebesar $82.1 \%$ dengan kualifikasi baik (B) dan siklus 2 sebesar $89.2 \%$ dengan kualifikasi sangat baik (SB).

Peningkatan perolehan skor pengamatan RPP ini disebabkan oleh perbaikan yang dilakukan peneliti pada setiap pertemuannya yang disesuiakan dengan saran dan masukan yang diberikan observer.

\section{Proses Pembelajaran Menggunakan Model Kooperatif Tipe TGT Berbantuan Media Permainan Ular Tangga \\ Proses pembelajaran menggunakan}

model kooperatif tipe TGT berbantuan media permainan ular tangga merupakan pembelajaran yang mengikuti sintaks/langkahlangkah pembelajaran model kooperatif tipe TGT yang dikombinasikan dengan media permainan ular tangga.

Pada penelitian ini proses pembelajaran menggunakan model kooperatif tipe TGT berbantuan media permainan ular tangga dilakukan selama 2 siklus dengan siklus 1 sebanyak dua kali pertemuan dan siklus 2 sebanyak satu kali pertemuan. Model kooperatif tipe TGT mempunyai 5 langkah yang terdiri dari penyajian kelas, pembentukan kelompok/belajar kelompok, permainan, turnamen dan penghargaan kelompok.

Berdasarkan hasil pengamatan yang dilakukan oleh observer selama penelitian didapatkan hasil bahwa setiap pertemuan 
proses pembelajaran yang dilakukan oleh peneliti mengalami kenaikan yang signifikan. Hasil rekapitulasi pengamatan proses pembelajaran dengan menggunakan model kooperatif tipe TGT berbantuan media permainan ular tangga dapat dilihat pada gambar berikut ini:

Rekapitulasi Data Pengamatan Proses Pembelajaran dengan Penerapan Menggunakan Model Kooperatif Learning Tipe TGT Berbantuan Media Permainan Ular Tangga (Aspek Guru)

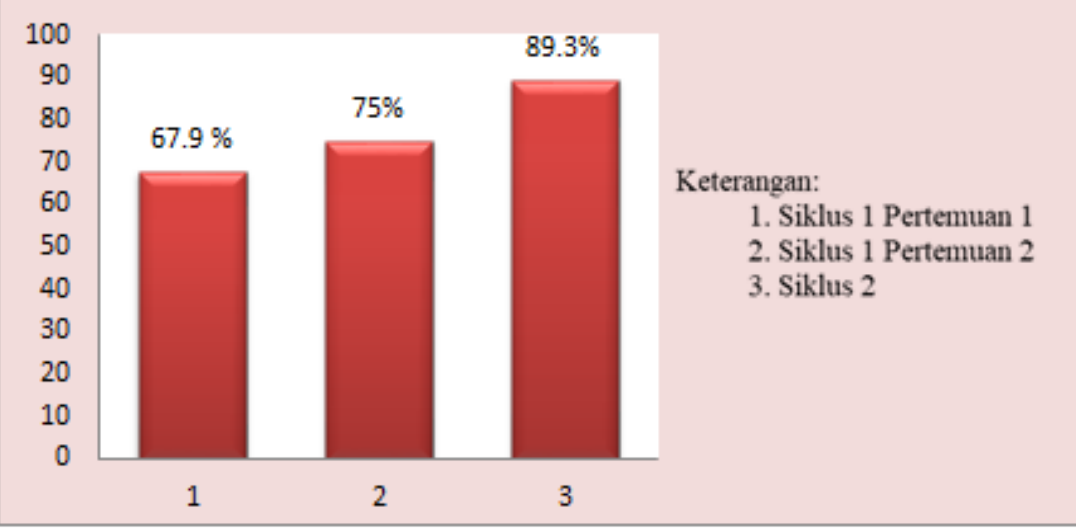

Gambar 2. Proses Pembelajaran Menggunakan Model Kooperatif Tipe TGT Berbantuan Media Permainan Ular Tangga (Aspek Guru)

Melalui gambar di atas dapat diketahui bahwa kualifikasi proses pembelajaran menggunakan model kooperatif tipe TGT berbantuan media permainan ular tangga (Aspek guru) mengalami peningkatan yang signifikan. Hal ini terlihat dari perolehan persentase proses pembelajaran pada siklus 1 pertemuan 1 sebesar $67.9 \%$, pada siklus 1 pertemuan 2 kualifikasi proses pembelajaran meningkat sehingga memperoleh persentase sebesar $75 \%$. Sedangkan pada siklus 2 perolehan skor proses pembelajaran aspek guru meningkat menjadi $89.3 \%$

\section{Aktivitas Belajar Siswa}

Pada penelitian ini aktivitas belajar siswa merupakan variable utama yang diukur. Penliti ingin membuktikan peningkatan aktivitas belajar siswa menggunakan model kooperatif tipe TGT berbantuan media permainan ular tangga.

Menurut Diedrich (Aminah, 2018) aktivitas belajar siswa terdiri dari 8 aspek yaitu: aktivitas visual, lisan, mendengarkan, menulis, menggambar, fisik, mental dan emosional. Pada penelitian ini pengamatan aktivitas belajar siswa dilakukan sebelum penelitian (pra penelitian) untuk mengetahui bagaimana kualifikasi aktivitas belajar siswa sebelum diterapkan model pembelajaran kooperatif tipe TGT berbantuan media permainan ular tangga. Hasil observasi aktivitas belajar siswa pra peneltian memperoleh persentase $50.1 \%$ dengan kualifikasi kurang (D).

Setelah mendapatkan kualifikasi aktivitas belajar siswa pra penelitian maka peneliti menjalankan pembelajaran dengan tujuan meningkatkan aktivitas belajar siswa menggunakan model kooperatif tipe TGT berbantuan media permainan ular tangga. Penelitian ini dibagi menjadi dua siklus, dimana siklus 1 terdiri dari dua pertemuan dan siklus 2 terdiri dari satu pertemuan. Kualifikasi 
setiap aspek aktivitas belajar siswa terus meningkat disetiap pertemuannya, peningkatan kualifikasi aktivitas belajar siswa tersebut secara rinci dapat dilihat pada gambar berikut:

Rekapitulasi Perolehan Skor Aktivitas Belajar Siswa

घJenis Aktivitas PraPeneltian J Jenis Aktivitas Siklus 1 Pertemuan 1 uJenis Aktivitas Siklus 1 Pertemuan 2 Jenis Aktivitas Siklus 2

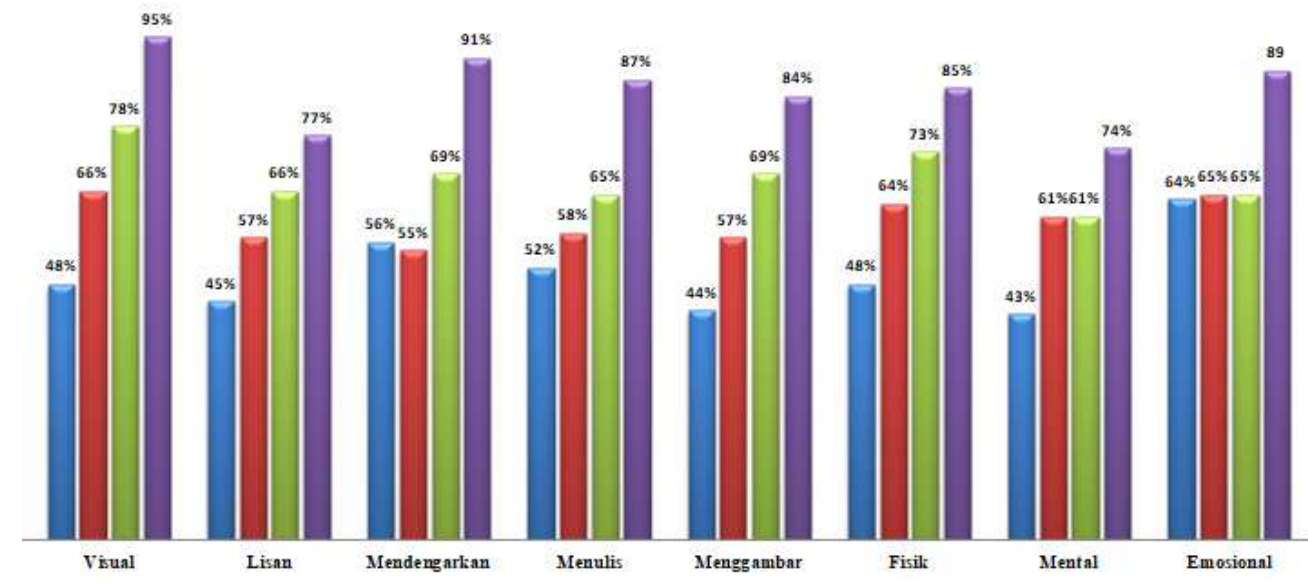

Gambar 3 Aktivitas Belajar Siswa

Melalui gambar di atas dapat diketahui bahwa kedelapan aspek aktivitas belajar terus mengalami peningkatan yang signifikan. Hal ini terlihat dari perolehan skor pada tiap aspek aktivitas belajar siswa yang terus mengalami kenaikan, seperti pada aspek aktivitas visual terlihat bawah skor yang diperoleh saat pra penelitian sebesar $48 \%$ yang kemudian menjadi $66 \%$ pada siklus 1 pertemuan 1 , meningkat menjadi $78 \%$ pada siklus 1 pertemuan 2 dan meningkat menjadi $95 \%$ pada pembelajaran di siklus 2. Pada aspek aktivitas lisan terlihat bahwa skor yang diperoleh saat pra penelitian sebesar $45 \%$ yang kemudian menjadi $57 \%$ pada siklus 1 pertemuan 1 , meningkat menjadi $66 \%$ pada siklus 1 pertemuan 2 dan meningkat menjadi $77 \%$ pada pembelajaran di siklus 2. Pada aspek aktivitas mendengarkan terlihat bahwa skor yang diperoleh saat pra penelitian sebesar 55\% yang kemudian menjadi $56 \%$ pada siklus 1 pertemuan 1 , meningkat menjadi $69 \%$ pada siklus 1 pertemuan 2 dan meningkat menjadi $91 \%$ pada pembelajaran di siklus 2 . Pada aspek aktivitas menulis terlihat bahwa skor yang diperoleh saat pra penelitian sebesar 52\% yang kemudian menjadi $58 \%$ pada siklus 1 pertemuan 1 , meningkat menjadi $65 \%$ pada siklus 1 pertemuan 2 dan meningkat menjadi $87 \%$ pada pembelajaran di siklus 2 . Pada aspek aktivitas menggambar terlihat bahwa skor yang diperoleh saat pra penelitian sebesar $44 \%$ yang kemudian menjadi $57 \%$ pada siklus 1 pertemuan 1 , meningkat menjadi $69 \%$ pada siklus 1 pertemuan 2 dan meningkat menjadi $84 \%$ pada pembelajaran di siklus 2. Pada aspek aktivitas lisan terlihat bahwa skor yang diperoleh saat pra penelitian sebesar $45 \%$ yang kemudian menjadi $57 \%$ pada siklus 1 pertemuan 1 , meningkat menjadi $66 \%$ pada siklus 1 pertemuan 2 dan meningkat menjadi $77 \%$ pada pembelajaran di siklus 2 . Pada aspek aktivitas fisik terlihat bahwa skor yang diperoleh saat pra penelitian sebesar $48 \%$ yang kemudian menjadi $64 \%$ pada siklus 1 pertemuan 1 , meningkat menjadi $73 \%$ pada siklus 1 pertemuan 2 dan meningkat menjadi $85 \%$ pada pembelajaran di siklus 2 . Pada aspek aktivitas mental terlihat bahwa skor yang diperoleh saat pra penelitian sebesar $43 \%$ yang kemudian menjadi $61 \%$ pada siklus 1 pertemuan $1,61 \%$ pada siklus 1 pertemuan 2 dan meningkat menjadi $74 \%$ pada pembelajaran di siklus 2. Pada aspek aktivitas 
emosional terlihat bahwa skor yang diperoleh saat pra penelitian sebesar $64 \%$ yang kemudian menjadi $65 \%$ pada siklus 1 pertemuan $1,65 \%$ pada siklus 1 pertemuan 2 dan meningkat menjadi $89 \%$ pada pembelajaran di siklus 2 .

Peningkatan aktivitas belajar siswa dari siklus pertama hingga siklus kedua juga dapat dilihat pada gambar berikut ini:

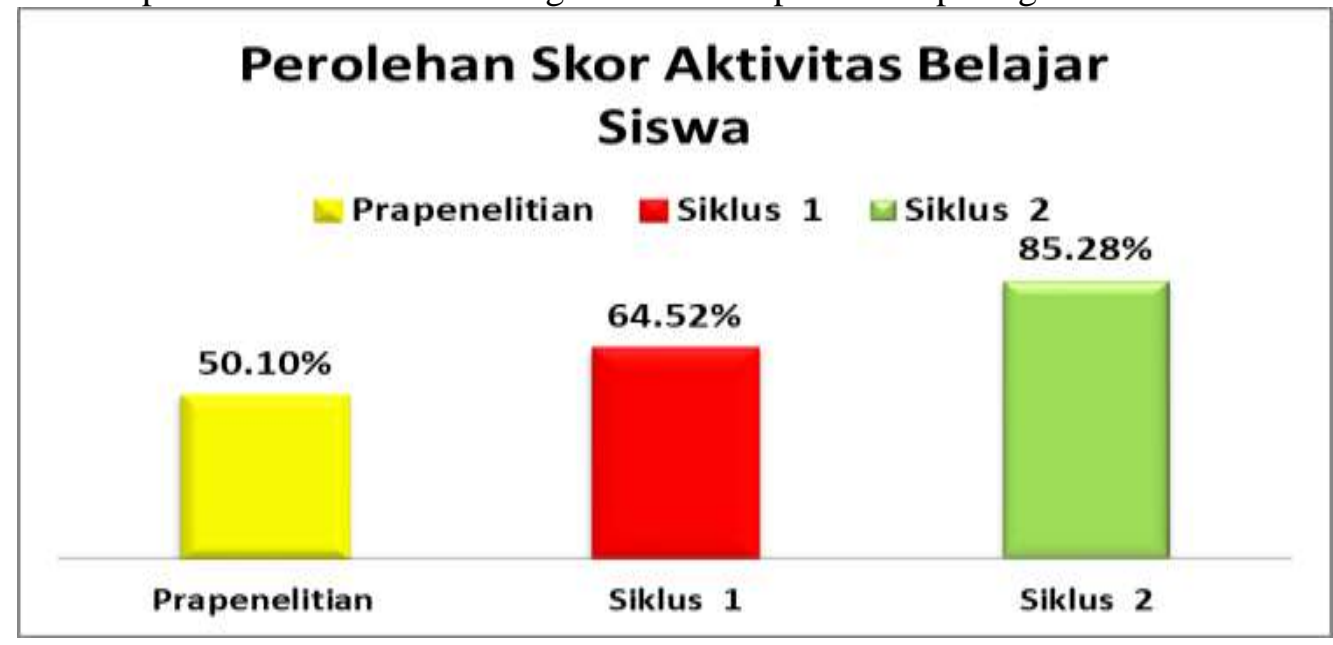

Gambar 4. Perolehan Skor Aktivitas Belajar Siswa

Melalui data pada gambar di atas dapat diketahui bahwa kualifikasi aktivitas belajar siswa terus mengalami peningkatan yang signifikan. Sebelum dilaksanakan penelitian, kualifikasi aktivitas belajar siswa di kelas VB masih tergolong rendah dengan persentase sebesar $50.10 \%$. Setelah dilakukan penelitian dengan menerapkan model kooperatif tipe TGT berbantuan media permainan ular tangga, aktivitas belajar siswa pada siklus satu mengalami peningkatan dengan persentase perolehan skor sebesar $64.52 \%$. Pelaksanaan pembelajaran disiklus 1 masih mengalami banyak kelemahan sehingga masih belum dapat meningkatkan kualifikasi aktivitas beklajar siswa secara signifikan. Setelah melakukan refleksi antar peneliti dan observer maka kekurangan pada pembelajaran disiklus 1 diperbaiki pada pembelajaran disiklus 2 sehingga kualifikasi aktivitas belajar siswa meningkat secara signifikan menjadi $85.28 \%$.

Kualifikasi aktivitas belajar siswa pada siklus 2 sebesar $85.28 \%$ sudah meemenuhi kriteria ketuntasan klasikal untuk aktivitas belajar, secara keseluruhan model pembelajaran kooperatif tipe TGT berhasil meningkatkan aktivitas belajar siswa dikarenakan kualifikasi aktivitas belajar siswa yang diperoleh pada siklus 2 sudah melebihi $75 \%$. Hal ini didukung oleh pendapat Mulyasa (Wibowo, 2016)yang menyatakan bahwa dari segi proses, pembelajaran dikatakan berhasil dan berkualitas apabila seluruhnya atau setidak-tidaknya sebagian besar $(75 \%)$ siswa terlibat aktif dalam proses pembelajaran. Apabila $\geq 75 \%$ siswa sudah melakukan aktivitas dalam proses pembelajaran dengan kategori baik, maka aktivitas belajar siswa sudah sesuai dengan yang diharapkan.

\section{SIMPULAN DAN REKOMENDASI}

Dari uraian data, hasil penelitian, dan pembahasan, simpulan yang dapat diambil dari penelitian ini, yaitu: (a) Rencana pelaksanaan pembelajaran (RPP) tematik terpadu pada kelas V SDN 13 Kapalo Koto kota Padang terdiri dari kegiatan awal pembelajaran, kegiatan inti pembelajaran, dan kegiatan penutup pembelajaran dengan menggunakan model kooperatif tipe Teams Games Tournament (TGT) berbantuan media permainan ular tangga. Hasil penelitian 
menunjukkan bahwa peningkatan RPP siklus I pertemuan I diperoleh nilai $75 \%$ dengan kualifikasi cukup (C), pada siklus I pertemuan 2 yang diperoleh dengan nilai sebesar $82.1 \%$ dengan kualifikasi baik (B), dan pada siklus II diperoleh nilai $89.2 \%$ dengan kualifikasi sangat baik (SB). (b) Pelaksanaan pembelajaran di kelas VB SDN 13 Kapalo Koto kota Padang terdiri dari kegiatan awal pembelajaran, kegiatan inti pembelajaran, dan kegiatan penutup pembelajaran dengan menggunakan model kooperatif tipe Teams Games Tournament (TGT) berbantuan media permainan ular tangga. Berdasarkan pengamatan yang dilakukan menggunakan lembar pengamatan proses pembelajaran aspek guru maka diperoleh hasil pengamatan pada siklus I pertemuan 1 sebesar $67.9 \%$ dikualifikasikan cukup (C), siklus I pertemuan 2 sebesar $75 \%$ dikualifikasikan cukup (C) dan pada siklus II mengalami peningkatan sebesar $89.3 \%$ dikualifikasikan sangat baik (SB). (c) Hasil pengamatan aktivitas siswa menggunakan model kooperatif tipe Teams Games Tournament (TGT) berbantuan media permainan ular tangga pada pembelajaran tematik terpadu di Kelas VB SD Negeri 13 Kapalo Koto Kota Padang yaitu pada siklus 1 sebesar $64.52 \%$ dan meningkat secara signifikan menjadi $85.28 \%$ pada pertemuan siklus 2. Berdasarkan data tersebut dapat dikatakan bahwa penerapan model kooperatif tipe Teams Games Tournament (TGT) berbantuan media permainan ular tangga pada pembelajaran tematik terpadu di Kelas VB SDN 13 Kapalo Koto Kota Padang dapat meningkatkan aktivitas belajar siswa.

Berdasarkan simpulan di atas maka saran yang dapat diberikan kepada guru sebagai tenaga pendidik untuk dapat mencoba menerapkan model pembelajaran kooperatif tipe Teams Games Tournament (TGT) berbantuan media permainan ular tangga dalam proses pembelajaran agar tercipta suasana kelas yang menyenangkan dan menstimulasi aktivitas belajar siswa.

\section{DAFTAR PUSTAKA}

Agustin. M, Yensi. A. N, Rusdi. (2017). Upaya Meningkatkan Aktivitas Belajar Siswa Dengan Menerapkan Model Pembelajaran Problem Posing Tipe Pre Solution Posing di SMP Negeri 15 Kota Bengkulu. JP2MS, I(1): 66-72

Aminah, S. (2018). Hubungan Aktivitas Belajar Siswa Dengan Hasil Belajar Mata Pelajaran Pendidikan Agama Islam Siswa Kelas XI SMA Negeri 1 Batanghari Tahun Pelajaran 2016/2017. Undergraduate thesis, IAIN Metro.

Anggraeni. V, \& Muharram, A. (2018). Pengaruh Permainan Ular Tangga dalam Model Pembelajaran Kooperatif Tipe TGT Terhadap Motivasi dan Hasil Belajar Kimia Siswa Kelas X SMA Negeri 1 Masamba. Jurnal Chemica, 9 (1): 96-106.

Arikunto, S. (2015). Prosedur Penelitian Suatu Pendekatan Praktik. Jakarta: Rineka Cipta.

Bunga, M. Y. R. (2013). Meningkatkan Hasil Belajar Ipa Siswa Kelas IV SD Bala Keselamatan Jono Oge Melalui Penerapan Model Pembelajaran Kooperatif Tipe Teams Games Tournament. Elementary School of Education, 1(4): 1-12.

Chikmawati, Dyah, N, I. (2013). Penerapan Model Pembelajaran Kooperatif Tipe TGT (Team Games Tournament) Untuk Meningkatkan Hasil Belajar Matematika Kelas IV SD Negeri 02 Brujul Kecamatan Jaten Kabupaten Karanganyar Tahun 2012/2013. Skripsi Prodi PGSD, Universitas Muhammadiyah Surakarta: Tidak Diterbitkan.

Fitrizah, M, K. (2020) . The Influence Of Snake And Ladders Game To Improve Knowledge And Attitudes Of Elementary School Students About Stop Babs In Bandung City. The Indonesian Journal Of Public Health, 
15 (2), Halm 173-180.

Hamalik, O. (2013). Proses Belajar Mengajar. Sawo Raya: Bumi Aksara.

Jusman. (2021). Implementing Search, Solve, Create, Aad Share (SSCS) Learning Model to Improve Students' Critical Thinking Skills. Primary: Jurnal Pendidikan Guru Sekolah Dasar, 10 (2), 401-409. DOI: http://dx.doi.org/10.33578/jpfkip.v10i2 .8259 .

Kasih, A, P. (2020). Survei UNICEF: 66 Persen Siswa Mengaku Tak Nyaman Belajar di Rumah. Kompas. Jakarta: PT. Kompas Media Nusantara.

Maulidina, Z. (2018). Pengaruh Model Pembelajaran Kooperatif Tipe TGT Berbantuan Media TTS Terhadap Hasil Belajar Siswa. Jurnal JPSD, 4(2): 140-147

Meipina (2014). The Application of Snakes and Ladders Game in Teaching Vocabulary. International Conference on Education and Language (ICEL).
Vol 2. pp.380-387.

Sardiman, A.M, (2012). Interaksi dan Motivasi

Belajar Mengajar. Jakarta: Raja

Grafindo Persada

Susanna. (2017). Penerapan Teams games Tournament (TGT) Melalui Media Kartu Domino Pada Materi Minyak Bumi Siswa Kelas XI MAN Aceh Besar. Lantanida Journal, 5(2): 93105

Tarigan, D. (2014). Meningkatkan Aktivitas Belajar Siswa dengan Menggunakan Model Make A Match Pada Mata Pelajaran Matematika di Kelas V SDN 050687 Sawit Seberang. Jurnal Kreano, 5(1): 56-62

Wibowo, N. (2016). Upaya Peningkatan Keaktifan Siswa Melalui Pembelajaran Berdasarkan Gaya Belajar di SMK Negeri 1 Saptosari. Jurnal Electronics, Informatics, and Vocational Education (ELINVO), 1(2): 128-139. 